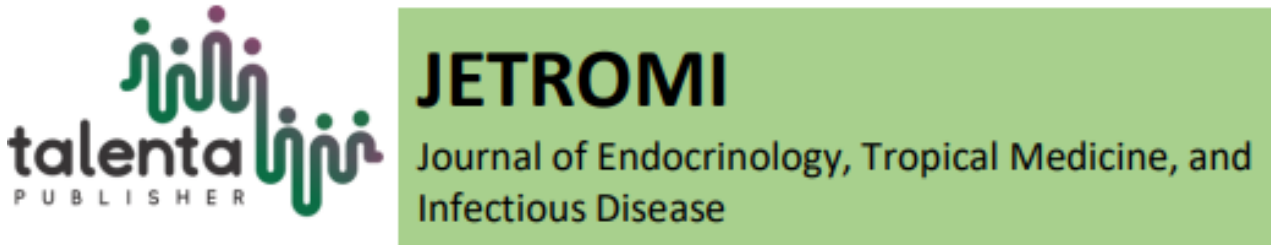

\title{
The Association between Triglycerides and Glucose (TyG) Index and Parameters of Metabolic Syndrome.
}

\author{
Sigit Anugerah Putra $\mathrm{SN}^{* 1}$, Dharma Lindarto ${ }^{2}$ \\ ${ }^{1}$ Department of Internal Medicine, Faculty of Medicine, University Sumatera Utara, Medan, North \\ Sumatera, Indonesia \\ ${ }^{2}$ Division of Endocrinologist, Department of Internal Medicine, Faculty of Medicine, University \\ Sumatera Utara, Medan, North Sumatera, Indonesia
}

\begin{abstract}
Background: The triglyceride and glucose index (TyG index) has become an attractive option due to the highly available and inexpensive biochemical markers for the diagnostic of insulin resistance (IR). This study aimed to investigate the association between TyG index and parameters of metabolic syndrome patients.

Method: A cross-sectional was conducted in outpatient Polyclinics of the EndocrineMetabolic division of RSUP H Adam Malik Medan. Criteria of Metabolic Syndrome (according to the new IDF definition, for a person to be defined as having the metabolic syndrome they must have:

Central obesity plus any two of the following four factors): (i) abdominal obesity: waist circumference of $\geq 80 \mathrm{~cm}$ in women and $\geq 90 \mathrm{~cm}$ in men in ASEAN, measured at the umbilical level in a standing position; (ii) systolic blood pressure (SBP) of $\geq 130 \mathrm{mmHg}$ or diastolic blood pressure (DBP) of $\geq 85 \mathrm{mmHg}$ (or treatment with antihypertensive medication), measured in all subjects using a validated digital electronic tensiometer in both upper limbs in a seated position after 15 minutes of rest; (iii) triglycerides levels (TG) of $\geq 150 \mathrm{mg} / \mathrm{dL}$ (1.7 $\mathrm{mmol} / \mathrm{L}$ ) or statin/fibrate treatment; HDL-cholesterol levels (HDL-C) of $<50 \mathrm{mg} / \mathrm{dL}$ in women and $<40 \mathrm{mg} / \mathrm{dL}$ in men.
\end{abstract}

Result: Based this study, there were 20 metabolic syndrome patients. From the data, all patients are obese and HbAlc is normal. There is a significant relationship between TyG and HDL-C and TG ( $r=-0.60 ; p=0.005^{* *}$ and $r=0.88, p=0.001^{* *}$, respectively).

Conclusion: There is a significant relationship between TyG and HDL-C and TG of metabolic syndrome patients.

Keywords: TyG, Metabolic Syndrome Parameters \footnotetext{
Medan, North Sumatera, Indonesia

E-mail address: sigitanugerahputrasn@gmail.com

*Corresponding author at: Department of Internal Medicine, Faculty of Medicine, University Sumatera Utara, 


\section{ABSTRAK}

Latar Belakang : Triglyceride and glucose index (TyG index) menjadi pilihan penanda biokimia yang menarik, tersedia dan murah untuk mendiagnosa resistensi insulin (RI). Tujuan penelitian ini adalah untuk menyelidiki hubungan antara indeks $T y G$ dan parameter pasien sindrom metabolik.

Metode: Penelitian dilakukan secara potong lintang di Poliklinik rawat jalan Divisi Endokrine-Metabolik RSUP H Adam Malik Medan. Kriteria sindrom metabolik (menurut $I D F$, seseorang didefinisikan sebagai memiliki sindrom metabolik yang harus memiliki obesitas sentral ditambah dua dari empat faktor berikut): (i) obesitas: lingkar pinggang $\geq 80$ $\mathrm{cm}$ pada wanita dan $\geq 90 \mathrm{~cm}$ pada pria Asia, diukur pada tingkat umbilical dalam posisi berdiri; (ii) tekanan darah systolik (TDS) $\geq 130 \mathrm{mmHg}$ atau tekanan darah diastolik (TDD) $\geq 85 \mathrm{mmHg}$ (atau dengan pengobatan obat antihypertensif), diukur di semua subjek menggunakan tensiometer elektronik digital yang divalidasi di kedua anggota badan atas dalam posisi duduk setelah 15 menit istirahat; (iii) kadar trigliserida (TG) $\geq 150 \mathrm{mg} / \mathrm{dL}(1,7$ mmol/L) atau mendapat pengobatan statin/fibrate; Kadar kolesterol HDL $(H D L-C)<50$ mg/dL pada wanita dan < $40 \mathrm{mg} / d L$ pada pria).

Hasil: Dari penelitian 20 pasien sindrom metabolik, semua pasien adalah obesitas dan normal HbAlc. Ada hubungan yang signifikan antara TyG dan HDL dan TG (masingmasing $r=-0,60 ; p=0,005 * *$ dan $r=0,88, p=0,001 * *)$.

Kesimpulan: Ada hubungan yang signifikan antara $T y G$ dengan HDL dan TG pada pasien sindrom metabolik.

Kata Kunci: TyG, Parameter Sindrom Metabolik

Received 12 May 2021 | Revised 30 May 2021 | Accepted 31 May 2021

\section{Introduction}

Insulin resistance (IR) is one of the first metabolic abnormalities leading to the development of type 2 diabetes, and it is known to be a key mediator of its pathogenesis [1]. The hyperinsulinemic-euglycemic clamp (HIEC) is considered the current gold standard to determine IR [2]; however, it is a complicated and time-consuming method with limited applicability to research settings. As an alternative strategy, surrogate markers derived from faster and less costly biochemical measurements have been proposed [2,3]. To date, several IR surrogate markers such as HOMA-IR, TG/HDL, QUICKI, and the McAuley index have been studied with different sensitivities and specificities for IR [4,5].

Lately, the triglyceride and glucose index (TyG index) has become an attractive option due to the highly available and inexpensive biochemical markers needed for its calculation [6,7]. It is derived from fasting plasma glucose and fasting triglyceride levels. The diagnostic accuracy of the TyG index in identifying IR using the HIEC and HOMA-IR as reference standards has been tested in several studies. However, the lack of consistency in their findings limits its generalizability and utility as a diagnostic marker of IR. Therefore, we sought to conduct a 
systematic review to assess the body of evidence regarding the diagnostic accuracy of the TyG index in identifying $I R$ in adults.

Another risk factor for CVD in DMT2 is diabetic dyslipidemia. It consists of increased triglycerides (TG), reduced high-density lipoprotein cholesterol (HDL-C), and postprandial lipemia. In addition, low-density lipoprotein cholesterol (LDL-C) is converted to small, dense LDL that is more atherogenic. The serum triglyceride to high-density lipoprotein cholesterol (TG/ HDL-C) ratio, known as the atherogenic index of plasma, is one of the major risk factors for CVD and metabolic syndrome [8]. Higher TG/HDL C ratio has been associated with the presence of endothelial dysfunction [9]. Furthermore, TG/HDL-C ratio has been proposed as a marker of insulin resistance[10]. Quispe et al. [11] have shown that TG/HDL-C can also be a marker of glycemic control, especially in obese patients with DM2. An additional marker associated with insulin resistance is the triglyceride to glucose (TyG) index. It helps in the identification of subjects at high risk of CVD in asymptomatic subjects with DM2 [12].

This study aimed to investigate the association between TyG index and parameters of metabolic syndrome patients.

\section{Method}

A cross-sectional was conducted in outpatient polyclinics of the Endocrine-Metabolic division of RSUP H Adam Malik Medan. The study group consisted of 20 patients with diagnosed metabolic syndrome. Anthropometric measurements (height, weight, and waist circumference) were taken in all subjects. Body mass index (BMI) was calculated as body weight (in kilograms) divided by the square of body height (in meters). The main analysis was performed using the 2009 revision of the International Diabetes Federation (IDF) definition, requiring the presence of the following criteria: (i) abdominal obesity: waist circumference of $\geq 80 \mathrm{~cm}$ in women and $\geq 90 \mathrm{~cm}$ in men in ASEAN, measured at the umbilical level in a standing position; (ii) systolic blood pressure (SBP) of $\geq 130 \mathrm{mmHg}$ or diastolic blood pressure (DBP) of $\geq 85 \mathrm{mmHg}$ (or treatment with antihypertensive medication), measured in all subjects using a validated digital electronic tensiometer in both upper limbs in a seated position after 15 minutes of rest; (iii) triglycerides levels (TG) of $\geq 150 \mathrm{mg} / \mathrm{dL}(1.7 \mathrm{mmol} / \mathrm{L})$ or statin/fibrate treatment; HDL-cholesterol levels (HDL-C) of $<50 \mathrm{mg} / \mathrm{dL}$ in women and $<40 \mathrm{mg} / \mathrm{dL}$ in men. Diabetes was defined as fasting blood glucose (FBG) levels of $\geq 7 \mathrm{mmol} / \mathrm{L}$ and/or treatment with antidiabetic medications. Lipid profile examination is carried out using a spectrophotometer tool colorimetric enzymatic method or CHOD PAP parameters observed include total cholesterol, HDL cholesterol (High-Density Lipoprotein), LDL cholesterol (Low-Density Lipoprotein), and triglycerides [13].

According to a study by Salazar et al. insulin resistance cut-off is placed at the TyG index value of 4.49 , with a sensitivity of $82.6 \%$ and specificity of $82.1 \%$ (AUC $=0.889,95 \%$ CI: $0.854-0.924$ ). 
Subjects with an index of 4.49 or greater are likely to suffer from insulin resistance.The TyG equation $=\ln$ [Fasting triglyceride $(\mathrm{mg} / \mathrm{dl}) \times$ Fasting glucose $(\mathrm{mg} / \mathrm{dl})] / 2$. [14]

Statistical Analysis

SPSS 22.0 was employed for statistical analysis, and quantitative data were expressed in the form of $(\mathrm{X} \pm \mathrm{SD})$. Nonparametric tests are used to calculate the correlation between TyG and metabolic syndrome parameters, and $p<005$ was accepted as statistically significant.

\section{Result}

Based in this study, there were 20 metabolic syndrome patients. From the data, all patients are obese and $\mathrm{HbA1c}$ is normal (Table 1).

Table 1 Basic data of metabolic syndrome patients

\begin{tabular}{lc}
\hline \multicolumn{1}{c}{ Parameters } & X \pm SD $(\mathbf{n}=20)$ \\
\hline BMI $\left(\mathrm{kg} / \mathrm{m}^{2}\right)$ & $34.2 \pm 5.6$ \\
WC $(\mathrm{cm})$ & $98.4 \pm 11.1$ \\
SBP $(\mathrm{mmHg})$ & $127.0 \pm 20.2$ \\
DBP $(\mathrm{mmHg}$ & $81.7 \pm 10.9$ \\
FG $(\mathrm{mg} / \mathrm{dl})$ & $85.3 \pm 9.0$ \\
PPG $(\mathrm{mg} / \mathrm{dl})$ & $105.0 \pm 22.3$ \\
HbA1c $(\%)$ & $5.6 \pm 0.4$ \\
HDL-C (mg/dl) & $48.8 \pm 16.43$ \\
TG $(\mathrm{mg} / \mathrm{dl})$ & $152.8 \pm 66.6$ \\
TyG index & $4.8 \pm 0.7$
\end{tabular}

Based in table 2. There is a significant relationship between TyG and HDL-C and TG of parameter of metabolic syndrome.

Table 2 Relationship between TyG and parameter of metabolic syndrome

\begin{tabular}{lcc}
\hline \multicolumn{1}{c}{ Parameters } & r & p \\
\hline BMI $\left(\mathrm{kg} / \mathrm{m}^{2}\right)$ & 0.19 & 0.401 \\
WC $(\mathrm{cm})$ & 0.33 & 0.147 \\
SBP $(\mathrm{mmHg})$ & -0.25 & 0.277 \\
DBP $(\mathrm{mmHg}$ & -0.41 & 0.072 \\
FG $(\mathrm{mg} / \mathrm{dl})$ & 0.31 & 0.176 \\
PPG $(\mathrm{mg} / \mathrm{dl})$ & -0.20 & 0.376 \\
HbA1c $(\%)$ & 0.27 & 0.248 \\
HDL-C $(\mathrm{mg} / \mathrm{dl})$ & -0.60 & $\mathbf{0 . 0 0 5 * *}$ \\
TG $(\mathrm{mg} / \mathrm{dl})$ & 0.88 & $\mathbf{0 . 0 0 1} * *$ \\
**p $<0.01$ & &
\end{tabular}




\section{Discussion}

The hyperinsulinemic-euglycemic clamp (HIEC) and HOMA-IR were used as the reference standard in the majority of the studies. Diagnostic accuracy varied according to the reference standard and the definition used to identify IR. In studies using HIEC, diagnostic performance varied with the insulin infusion rate and cutoff value. The highest sensitivity (96\%) achieved with a moderate specificity ( $85 \%$ ) was found with an insulin rate of $40 \mu \mathrm{U} / \mathrm{min} / \mathrm{m} 2$ and a cutoff value of 2.8 insulin $\mathrm{mg} / \mathrm{min} / \mathrm{kg}$ [15]. The TyG index has been linked to conditions such as metabolic syndrome, type 2 diabetes, and the risk of developing cardiovascular disease. Based on the above, studies that standardize and evaluate the TyG index capacity as an IR diagnostic marker should be encouraged. However, its applicability is limited due to the marked heterogeneity found in cutoff values and IR definitions among studies. Identifying subjects with IR is fundamental to develop novel treatments and preventive strategies for highly prevalent chronic diseases related to IR, such as obesity and type 2 diabetes [16]. The TyG index showed a strong diagnostic performance for cardiovascular risk factors and was independently associated with the SYNTAX score. The risk of MACEs significantly increased in the high TyG index group as compared with the low TyG index group [17]. In this study, the TyG index correlated significantly with TG and HDL-C of the parameters of metabolic syndrome patients.

\section{Conclusion.}

TyG is significantly correlated only with TG and HDL-C in metabolic syndrome patients.

\section{REFERENCES}

[1] B. C. Martin, J. H. Warram, A. S. Krolewski, . "Role of glucose and insulin resistance in development of type 2 diabetes mellitus: results of a 25 -year follow-up study," The Lancet, vol. 340, no. 8825, pp. 925-9, 1992.

[2] R. A. DeFronzo, J. D. Tobin, and R. Andres, "Glucose clamp technique: a method for quantifying insulin secretion and resistance," American Journal of PhysiologyEndocrinology and Metabolism, vol. 237, no. 3, pp. E214-E23, 1979.

[3] A. Borai, C. Livingstone, and G. A. Ferns, "The biochemical assessment of insulin resistance," Annals of Clinical Biochemistry, vol. 44, no. 4, pp. 324-42, 2007.

[4] J.P. Bastard, M.-E. Lavoie, V. Messier, D. Prud'homme, and R. Rabasa-Lhoret, "Evaluation of two new surrogate indices including parameters not using insulin to assess insulin sensitivity/resistance in non-diabetic postmenopausal women: a MONET group study," Diabetes \& Metabolism, vol. 38, no. 3, pp. 258-63, 2012.

[5] P. Almeda-Valdes, O. Y. Bello-Chavolla, C. R. Caballeros-Barragan et al., "Indices para la evaluacion de la resistencia a la insulina en individuos mexicanos sin diabetes," Gaceta de Mexico, vol. 154, no. 2, pp. S50-S5, 2018. 
[6] B. Singh and A. Saxena, "Surrogate markers of insulin resistance: a review," World Journal of Diabetes, vol. 1, no. 2, pp. 36-47, 2010.

[7] L. E. Simental-Mend' 1a, M. Rodr' 1guez-Mora' n, and F. Guerrero-Romero, "The product of fasting glucose and triglycerides as a surrogate for identifying insulin resistance in apparently healthy subjects," Metabolic Syndrome and Related Disorders, vol. 6, no. 4, pp. 299-304, 2008.

[8] Dobiasova M, Frohlich J. The plasma parameter log (TG/HDL-C) as an atherogenic index: correlation with lipoprotein particle size and esterification rate in apoBlipoprotein-depleted plasma FER(HDL. Clinical biochemistry. 34(7): 583-8. 2001

[9] Keles N, Aksu F, Aciksari G, Yilmaz Y, Demircioglu K, Kostek O, et al. Is triglyceride/HDL ratio a reliable screening test for assessment of atherosclerotic risk in patients with chronic inflammatory disease? North Clin Istanb.; vol.3, no 1: pp.39-45. 2016 DOI: $10.14744 /$ nci.2016.52824

[10] Chávez AG, Mendía LES, Argueta SE. Elevated triglycerides/HDL-cholesterol ratio associated with insulin resistance. Cir. vol. 79, no, 2: pp.126-31. 2011

[11] Quispe R, Martin SS, Jones SR. Triglycerides to high-density lipoprotein-cholesterol ratio, glycemic control and cardiovascular risk in obese patients with type 2 diabetes. Curr Opin Endocrinol Diabetes Obes. 23(2):150-156. 2016

[12] Lee EY, Yang HK, Lee J, Kang B, Yang Y, Lee SH, et al. Triglyceride glucose index, a marker of insulin resistance, is associated with coronary artery stenosis in asymptomatic subjects with type 2 diabetes. Lipids Health Dis.15(1): 155. 2016 doi: 10.1186/s12944016-0324-2.

[13] S. O’Neill and L. O'Driscoll. Etiology and Pathophysiology/Obesity Comorbidities Metabolic syndrome: A closer look at the growing epidemic and its associated pathologies. obesity reviews $16,1-12.2015$

[14] Salazar J, et al. Optimal cutoff for the evaluation of insulin resistance through triglyceride-glucose index: A cross-sectional study in a Venezuelan population. Version 3. F1000Res.6:1337. 2017

[15]F. Guerrero-Romero, L.E. Simental-Mendía, M. González-Ortiz et al., "The product of triglycerides and glucose, a simple measure of insulin sensitivity. Comparison with the euglycemic-hyperinsulinemic clamp," The Journal of Clinical Endocrinology \& Metabolism, vol. 95, no. 7, pp. 3347-3351, 2010

[16] T. P. Patel, K. Rawal, A. K. Bagchi, et al., "Insulin resistance: an additional risk factor in the pathogenesis of cardiovascular disease in type 2 diabetes," Heart Failure Reviews, vol. 21, no. 1, pp. 11-23, 2016.

[17] Mao Q, Zhou D,Li Y, Wang Y, Xu SC, Zhao X. The Triglyceride-Glucose Index Predicts Coronary Artery Disease Severity and Cardiovascular Outcomes in Patients with Non-ST Segment Elevation Acute Coronary Syndrome. Hindawi Disease Markers. 2019, Article ID 689153. https://doi.org/10.1155/2019/689153 